\title{
Nytt hjertekirurgisk sykehus i Astrakhan, Russland
}

\author{
For tre år siden ble det bygd et hjertekirurgisk sykehus - Astrakhan senter for kardiovaskulær kirurgi - \\ av russiske myndigheter. Det betjener en befolkning på mer enn 12 millioner mennesker som tidligere \\ ikke har hatt tilgang til hjertekirurgi. Urolige områder som Tsjetsjenia, Ingusjetia og Dagestan hører \\ med til sykehusets opptaksområde.
}

\author{
Mons Lie \\ uxmoli@ous-hf.no \\ Seksjon for internasjonalt samarbeid \\ Oslo universitetssykehus, Ullevål \\ Steinar Solberg \\ Thoraxkirurgisk avdeling \\ Oslo universitetssykehus, Rikshospitalet

\section{Harald Lindberg} \\ Thoraxkirurgisk avdeling \\ Oslo universitetssykehus, Rikshospitalet \\ Øyvind Skraastad \\ Anestesiavdelingen \\ Oslo universitetssykehus, Rikshospitalet
}

Fra begynnelsen av 1990-tallet har det vært et hjertekirurgisamarbeid mellom Universitetssykehuset Nord-Norge og Oslo universitetssykehus, Ullevål og Rikshospitalet, på den ene siden og Bysykehus nr. 1 i Arkhangelsk, Russland, på den andre siden $(1,2,3)$.

Sjefen for voksenhjertekirurgien, Igor Chernov, som har deltatt i dette samarbeidet, ble hentet fra Arkhangelsk til Astrakhan for å lede avdelingen der. Før oppstart i Astrakhan kom Igor Chernov sammen med sykehusets direktør, Dmitry Tarasov som også er hjertekirurg, og en gruppe av sykehusets ledende klinikere på besøk til Oslo universitetssykehus.

\section{En gammel by på Silkeveien}

Astrakhan ligger i deltaet til Europas største elv - Volga - ca. $150 \mathrm{~km}$ før elven møter Det kaspiske hav. Byen ble grunnlagt av Ivan den grusomme i 1558 og har en befolkning på drøyt 500000 mennesker. Stedet er et viktig møtested mellom den muslimske befolkningen og den russiskortodokse på Silkeveien mellom vest og øst.

Her bygde Ivan en borg, kreml, som et forsvarsverk for denne utposten i det store russiske riket. Borgen var den gang omgitt av elven på alle kanter. Nå har vannet funnet andre løp, og borgen ligger nyoppusset med sine tårn, festningsverk, kirker og garnisonsforlegninger, omgitt av byen med sine gamle trehus mellom store boligblokker.
Astrakhan har et universitet med et medisinsk fakultet fra 1918, et stort nytt teater og restauranter drevet av innflyttere fra Usbekistan og andre omkringliggende folkegrupper. Grensen til det selvstendige Kasakhstan går bare 100 kilometer fra byen. Et stykke ute i Det kaspiske hav går grensen mellom Astrakhan oblast (fylke) og Iran, som har en egen ambassade i byen.

Byen har svært lite turisme, selv om den er kjent for rike fiske- og jaktmuligheter, i tillegg til støren og den sorte kaviaren. Under havbunnen i Det kaspiske hav er det mye olje og gass. Havnen med de høye kranene, og de store helikoptrene på flyplassen, vitner om stor aktivitet.

I det postsovjetiske Russland er religion viktig. En tredel av befolkningen er muslimer. De skiller seg ikke ut på gaten fra sine russisk-ortodokse medborgere, og de religiøse gruppene lever side om side, uten konflikter, med sine moskeer og sine kirker.

\section{Desentralisering av høyspesialisert medisin}

Astrakhan senter for kardiovaskulær kirurgi har 167 senger, fire operasjonsstuer og topp moderne røntgenutstyr og laboratorier. Her er to avdelinger for voksenhjertekirurgi med 50 senger hver, en for barnehjertekirurgi med 17 senger, og en arytmiavdeling med 50 senger. Det er en intensivavdeling for voksne og en for barn. Sykehuset har 700 ansatte, hvorav 125 leger og 250 syke-

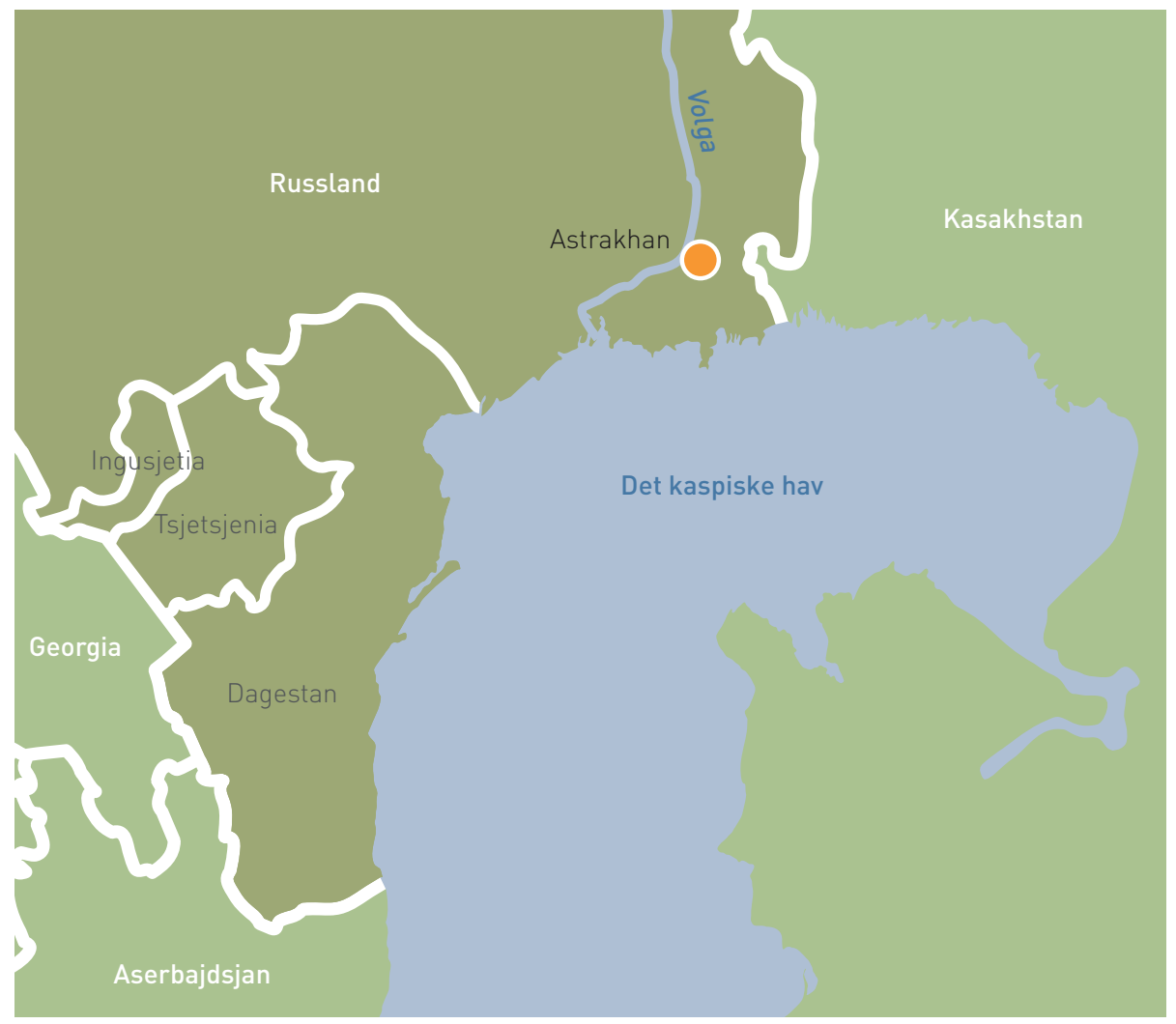

Opptaksområdet til sykehuset i Astrakhan er enormt, også pasienter fra Tsjetsjenia, Ingusjetia og Dagestan hører til her 
pleiere. I løpet av de første tre årene er det blitt utført 11500 behandlingsprosedyrer og 72000 undersøkelser, og sykehuset har 6000 innlagte pasienter i året (Dmitry

Tarasov, personlig meddelelse).

All undersøkelse og behandling er gratis. Statlige myndigheter dekker alle sykehusets utgifter. Hittil er det blitt betalt per pasientbehandling, men fra neste år vil sykehuset få et fast budsjett ledsaget av krav om et avtalt antall prosedyrer. Kostnadsrammen for en operativt behandlet pasient er om lag 70000 norske kroner, uansett hvilket operativt inngrep som blir utført, og lengden på sykehusoppholdet. Dette gir god fortjeneste på enkle inngrep som forløper rutinemessig, mens det lett blir tap i regnskapet ved kompliserte prosedyrer der man bruker implantater, eller hvis det oppstår postoperative komplikasjoner. Allikevel mener Tarasov at økonomien i liten grad styrer valget av behandlingsstrategi, for eksempel foretar man kun 1,5 perkutan koronar intervensjon (PCI) for hver koronaroperasjon.

Her drives topp moderne kirurgi både på voksne og barn. Vi så perkutan venehøsting, miniinvasiv mitralklaffekirurgi og Ross-operasjoner for aortaklaffesykdom. På kongenittsiden var vi med på en «arterial switch» for transposisjon av de store arteriene og lukking av ventrikkel septum defekt (VSD), via høyresidig thorakotomi.

På avdelingen hvor Igor Chernov er sjef, er det tre overleger og tre utdanningskandidater som til sammen gjør drøyt 1000 åpne hjerteoperasjoner årlig. I tillegg opererer de carotisstenoser, torakal aorta og i noen grad abdominal aorta, men ingen lunger. Avdelingen har tre faste kardiologer. Anestesilegene betjener alle avdelingene uten fast avdelingstilknytning.

Legene er rekruttert fra hele Russland. De er unge, og arbeidet er konsentrert om den kliniske virksomheten med minimale administrative belastninger. Sykehuset er lite og nyter godt av småsykehusfordelene. Ledelsen er nært knyttet til den daglige kliniske virksomheten. Sykehusdirektør Dmitry Tarasov utfører selv av og til hjerteoperasjoner. Den yngste av overlegene er 31 år gammel og gjør nesten 300 hjerteoperasjoner årlig.

Samarbeidet er godt, og det er oversiktlige forhold. Operasjonsstuene er utstyrt med det aller nyeste av utstyr, og man får inntrykk av at forholdene er lagt maksimalt til rette for klinisk utfoldelse. Det synes ikke å være spart på noe, og det arbeides mye og intenst. Utdanningskandidatene kommer rett fra studiet og arbeider ulønnet i to år. Blir de så akseptert, begynner de å operere og får da lønn.

Hva med ventelister, pasientseleksjon og transport i dette enorme området, som er så stort som Frankrike? Hvordan er etterbehandlingen og rehabiliteringen? Pasientene henvises stort sett av kardiologer i distriktet. Sjefen på barnehjertekirurgisk avde-

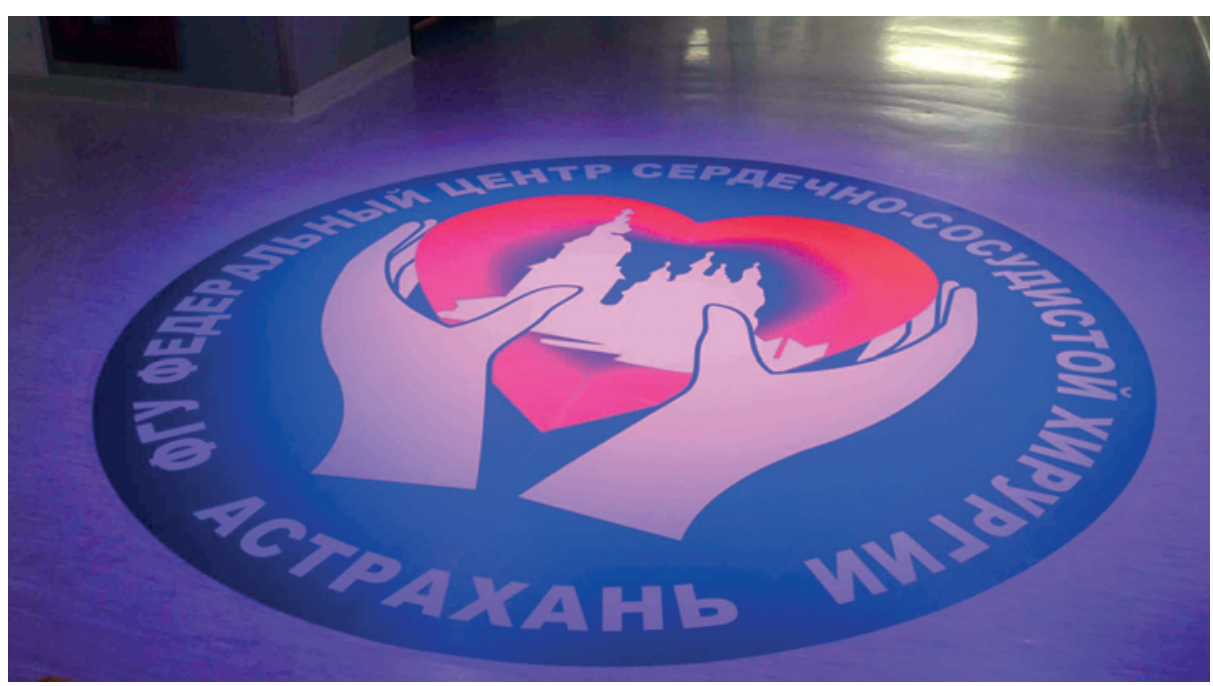

Sykehusets logo, som her pynter gulvet i en av korridorene. Foto Steinar Solberg

ling reiser ofte ut til distriktene, der han foretar polikliniske undersøkelser av barn og vurderer operasjonsindikasjon. Det er uhyre sjelden at kardiologer henviser pasienter eldre enn 65 år.

Sykehuset har en liten venteliste, og pasientene kan stort sett velge når de vil legges inn til operasjon. All transport foregår med bil og jernbane. Det finnes ingen flyplasser i sykehusets opptaksområde, bortsett fra i selve Astrakhan by. Dette begrenser tilgangen av øyeblikkelig hjelp, slik at sykehuset bare hadde seks akutte aortadisseksjoner, type A, foregående år, og ingen perkutan koronar intervensjon ved akutt hjerteinfarkt.

\section{«Det er tydelig at russiske myndigheter ser medisinen som et middel for å holde dette} enorme landet samlet»

Per i dag eksisterer det ingen rehabiliteringstilbud, men det er under planlegging. Oppfølging av pasienter i periferien, med for eksempel blodfortynning etter klaffekirurgi, er til tider vanskelig.

\section{Ny trend}

Tradisjonelt har høyspesialisert medisin i Russland vært sentralisert til Moskva, Sankt Petersburg og noen få andre byer. Verken før, under eller etter Sovjet-tiden er det medisinske tilbudet til befolkningen blitt økonomisk eller politisk prioritert.

Astrakhan senter for kardiovaskulær kirurgi representerer en positiv endring av denne tradisjonen. Vladimir Putin har besøkt sykehuset to ganger. Det er ikke bare økonomisk man satser her. Som en bekreftelse på at de statlige myndighetene prioriterer den medisinske desentraliseringen, har de i tillegg bygd syv slike sentre $i$ andre deler av Russland som tidligere ikke har hatt hjertekirurgi. Til sammen er det ved disse sentrene det siste året blitt operert 30000 pasienter (Dmitry Tarasov, personlig meddelelse).

Myndighetene planlegger liknende desentraliserte, høyspesialiserte sykehus hvor man skal konsentrere seg om henholdsvis hofteprotesekirurgi, traumatologi og kardiologi. De legger altså opp til mer spesialiserte institusjoner fremfor komplette sykehus. Helsebudsjettet i Russland er helt klart blitt mer prioritert under Vladimir Putin. Det er tydelig at russiske myndigheter ser medisinen som et middel for å holde dette enorme landet samlet, og at det å gi folk helsetjenester er viktig for å bekjempe befolkningsnedgangen og mye av uroen som truer denne stormakten.

For oss som har fulgt russisk medisin i Nordvest-Russland siden begynnelsen av 1990-tallet, er det en spennende endring som her synes å skje. Russernes sterke ønske om faglig kontakt med spesialisert vestlig medisin må vi som naboland imøtekomme. Her ligger en interessant utfordring også for norsk medisin.

\section{Mons Lie (f. 1938)}

er spesialist i generell kirurgi, karkirurgi og thoraxkirurgi. Han er tidligere avdelingssjef ved Thoraxkirurgisk avdeling, Oslo universitetssykehus, Ullevål og nå rådgiver ved Seksjon for internasjonalt samarbeid.

Forfatter har fylt ut ICMJE-skjemaet og oppgir ingen interessekonflikter. 


\section{Steinar Solberg (f. 1953)}

er spesialist i generell kirurgi, karkirurgi og thoraxkirurgi og overlege ved Thoraxkirurgisk avdeling, Oslo universitetssykehus, Rikshospitalet.

Forfatter har fylt ut ICMJE-skjemaet og oppgir ingen interessekonflikter.

\section{Harald Lindberg (f. 1945)}

er spesialist i generell kirurgi, karkirurgi og thoraxkirurgi. Han er seksjonsoverlege for kirurgi av medfødte hjertesykdommer og professor ved Universitetet i Oslo.

Forfatter har fylt ut ICMJE-skjemaet og oppgir ingen interessekonflikter.

\section{Øyvind Skraastad (f. 1958)}

er spesialist i anestesiologi og konstituert klinikkleder ved Akuttklinikken, Oslo universitetssykehus.

Forfatter har fylt ut ICMJE-skjemaet og oppgir ingen interessekonflikter.

\section{Litteratur}

1. Solberg S, Lie M. Lenin lever! Tidsskr Nor Lægeforen 1999; 119: 404-5.

2. Lie M, Solberg S. Fallots tetrade og Sovjetunionens fall. Tidsskr Nor Lægeforen 2004; 124 : 382-3.

3. Horjen AW, Tungusov D, Chernov I et al. Pediatric cardiac surgery in Northern Russia. Results from an international cooperative program. Scand Cardiovasc J 2011; 45: 187-92.

Mottatt 13.1. 2012, første revisjon innsendt 24.1. 2012, godkjent 26.1. 2012. Medisinsk redaktør

Merete Holtermann. 